DOI https://doi.org/10.36059/978-966-397-225-1-4

\title{
INFORMATION CIVILISATION: \\ REVISITING THE FORMATION ISSUE OF A CONTEMPORARY SCIENTIFIC VIEW OF THE WORLD
}

\section{Horban Yurii}

\section{INTRODUCTION}

The information space of culture in general and cultural practices related to the concentration, transformation and preservation of information as a resource of humanitarian background holders (libraries, archives, museums, exhibition and showrooms) is subjected to scientific scrutiny in Computer Studies, Cybernetics, Social Studies, Cultural Ecology, Communicology. After all, in the context of differential research, the concept of information is either overly universalised, mythologised, or reduced to quantitative models of information measurement, which postulates its "neutrality" and "abstractness".

However, the problem is not limited to the categorical mechanism as "product-service". It is necessary to go beyond the sociological, economic, and communicative models of the information space of culture and define a broader paradigm outside the interpretive framework of "ideal - material", "technology - production", etc. We are talking about ontological statements of the concept of "information" as a cultural phenomenon. We should note instantly that we are talking about information as a certain category of cultural creation, which determines the ontology of the method of "setting" information messages in society. The transcendental mode of information as a category of culture raises the questions how information happens in the cultural space, the phenomenological mode - how this possibility appears in the world, and the dialectical mode - how information is transformed into its opposite. In fact, the ontology of information is presented as possible, available, post-apparent, transformed into another reality.

To get closer to the proceeding system, cultural understanding of information, it is necessary, in our opinion, not to construct priori information models of society, culture, civilisation, production, etc., but to reconstruct the cultural ontology of the phenomenon of Information, its cultural "self-sufficiency" to outline the transcendental (ideal) context of this self-sufficiency and determine the threshold (ontological transcendence) of the phenomenon transition of the information to another (another phenomenon as the reality of culture, which is no longer informational). 


\section{Information: Influence on Cultural Integrity}

D. Bell creates a mythogenic position regarding the role of information in the formation of an information society, as well as a "post-industrial civilisation" and notes that, in contrast to commodity production, the production of services arises: "The concept of a post-industrial society concerns mainly changes in the social structure, how the economy is transformed and the system of employment is changing, as well as new relationships between theory and empiricism, especially between science and technology" information society is the method of transferring information as the dominant of cultural creativity. The fact that information technology producers operate autonomously becomes constitutive for determining the type of social society.

D. Bell writes: "By using the term 'services' as a generic term, we face a risk of making a mistake about the current social trends. Many agricultural societies, such as society in India, have a high proportion of people employed in the service sector (for example, home services), since labour here is cheap and, of course, does not find demand on the market. In an industrial society, various types of services tend to grow due to the need for additional assistance to production, for example, transportation and distribution. But in a post-industrial society, the emphasis is on different types of services. If we distribute services into groups for personal (small shops, laundries, garages, beauty rooms), business and finance, real estate, insurance; transportation, communications and utilities, healthcare, education, research and development, management; then we will see the growth of the last category of services, which is decisive for a post-industrial society. And it is the category that personifies the growth of the new intellectual society - in universities, research organisations, management"2. However, such argumentation was criticised, in particular, F. Webster argues that empirical facts on the provision of services in the information space are not lead to a change in the type of social relations, the ideal model of information governance is only a virtual abstraction of the community and not a regulatory mechanism in the capitalist production era.

"Services allocated to a special sector," notes F. Webster, "are a speculative category of statisticians who are engaged in finding out

${ }^{1}$ Bell D. (1996) Prykhid postindustrialnoho suspilstva [The arrival of post-industrial society]. Suchasna zarubizhna sotsialna filosofiia [Modern foreign social philosophy]. Kyiv: Lybid, p. 206.

${ }^{2}$ Bell D. (1996) Prykhid postindustrialnoho suspilstva [The arrival of post-industrial society]. Suchasna zarubizhna sotsialna filosofiia [Modern foreign social philosophy]. Kyiv: Lybid, pp. 210-211. 
employment in economic sectors and who need to highlight everything that is not the primary and secondary sectors, describe a basket of different activities, from real estate to massage and computer rooms, from transport and administration to the entertainment industry. The emphasis on the isolated nature of the service industry is only a convention of the classification that separates the tertiary sector from the other two, and it is misleading. This social construct is the separation of a service category which, although it depends on agriculture and industrial sectors, allows Bell with all his strong arguments to argue that the service sector will grow, relying on growing productivity in the primary and secondary sectors" ${ }^{3}$. It is also pointed the naivety of determining the differences between the nature of a product (material) and a service that is allegedly "nonmaterial", as information as a whole is considered "nonmaterial".

Phenomenological signs of information are systematised and described according to technological, economic, corporate, spatial, cultural characteristics. So, information is understood as a kind of "abstract judgment" that acquires its attributes in the context of functioning. This type of "ascent from the abstract to the concrete" was subjected to hypercriticism by F. Webster: "We propose to fix on the meaning and content of information. The first definition of information that comes to mind is semantic: information has meaning; it has an object; it is a piece of information about a person or something, or a motivation to act. <...> In search of a quantitative approach to the definition of information, one can turn to the classical information theory of Claude Shannon and Warren Weaver (1949), which uses a definition of information that differs from the usual semantic one. According to this theory, information is a quantity that is measured in "bits", defined as the symbols frequency probabilities. This definition arose from the need for communications technology engineers who are interested in measuring stored and transmitted characters based on a binary system (on-off, yes-no, 0-1). <...> In everyday life, when we receive or exchange information, we, first of all, assess its significance and value: is it significant, accurate, meaningless, attractive, competent or useful? But for information theory, which underlies many dimensions of the information explosion, these parameters are not essential. This theory defines information regardless of its content, considers it as parts of the physical world like energy or matter" 4 .

3 Webster F. (2003) Teorii informatsionnogo obshchestva [Information Society Theories]. Moscow: Aspekt Press, p. 65.

${ }^{4}$ Webster F. (2003) Teorii informatsionnogo obshchestva [Information Society Theories]. Moscow: Aspekt Press, pp. 34-35. 
The mythological information ontology is frankly defended by T. Stoner: "Information exists. To exist, it does not need to be perceived. To exist, it does not need to be understood. It does not require mental effort for its interpretation. To exist, it does not need to make sense. It exists" .

"Such a definition of information meets not only the technological and spatial concepts of the information society (when the amount of stored, processed and transmitted information serves as an indicator of productivity), because in the economic concept we are faced with a similar ignorance of the information content", notes F. Webster ${ }^{6}$. After all, not only the content is ignored, the cultural ontology of the information phenomenon is ignored; its transcendentality is postulated as an eternal ideal being. The etymology of the "information" concept comes from lat. informātiō "interpretation, representation, concept of something", informare "to provide a form, to teach; think, represent" ". The phenomenon of information is defined by way of perception as: visual, sound, tactile, olfactory, gustatory; by presentation form: text, numerical, graphical, audiovisual; by appropriation: mass, unique, secret, personal; by value: relevant, reliable, understandable, complete, useful; according to the truth: true, false; by type of provision: a place of origin, stage of processing, review mode, stability, control function ${ }^{8}$.

It is necessary to carry out a culturological reconstruction of information, which can be presented as a kind of model synthesis - the projection of culture and reflection models on a certain phenomenologically defined informātiō contest, which will allow fixing not a lot of phenomenological signs of information transformation. In particular a transition to something another - another extra-informational cultural phenomenon, but its specific reality, which can be defined as the unity of phenomenological and essential informātiō realities, which can be defined in phenomenological and semiotic implications.

Let's start with reflection characteristics as a kind of information "rotation". Yu. Lehenkyi characterises the reflection typology as a cultural phenomenon: "Reflection carries thought, comprehension, carries a reflex, activity, it can be topologically arranged as a four-vector system. This is a

5 Stonier T. (1990) Information and the Internal Structure of the Universe: An Exploration into Information Physics. London: Springer-Verlag, p. 21.

6 Webster F. (2003) Teorii informatsionnogo obshchestva [Information Society Theories]. Moscow: Aspekt Press, p. 35.

${ }^{7}$ Informatsiya [Information]. Retrieved from: https://ru.wikipedia.org/wiki (accessed 9 October 2020).

${ }^{8}$ Informatsiya [Information]. Retrieved from: https://ru.wikipedia.org/wiki (accessed 9 October 2020). 
reflection from the middle of practice, the usual way of thinking for an artist who has become a theorist, writes treatises, does not really care about comprehending the treatises of other artists or comprehending already developed thoughts in the context of other mental practices. This is how Malevich, Vitruvius, this is how Leonardo da Vinci wrote. Reflection on practice is already specialised reflection, which belongs to theorists. These are art historians, philosophers, aesthetics who specifically work in the world of ideas, horizontally compare one theory with another and build their paradigm in the context of various paradigms. The reflection of theorists is less productive but more reproductive. If the reflection that goes on in practice is productive, creative and emanative as an expression of a certain source of thought that belonged to the god of Ancient Greece - the Creator or the God of the Middle Ages, the god of post-modernism, then reflection on practice is a more closed, generalising reflection.

If we consider another vector or another bundle of reflective axes, then there are other relations: reflection into oneself and reflection into something else. Reflection into oneself is the comprehension of something that is returned to the world of consciousness. It is consciousness that becomes the only, wide and large world. <... > Reflection into something else is a type of imperative, transcendental reflection".

This matrix of the reflective space of cultural creation can be correlated with the leading constants of cultural dialogue as a constitutive factor of modelling in the culture of world-building. Yu. Lehenkyi writes: "We consider culture as a system that consists of subsystems of behaviour, state, activity (synchronous aspect); as a universal trinomial of culture creation, consisting of the main constitutive relations "nature-culture", "cultureculture", "nature - (culture - culture) - culture)" - the diachronic aspect. We argue that each culture as integrity at every minute of its existence includes the sphere of states (the phenomenological aspect of culture creation), behaviour (the aspect of managing activities using axiological orientation), the sphere of activity (the aspect of self-realisation, adaptation, objectification of human action in creativity).

Each culture has its own specific dialogue of cultural relations (for example, the Middle Ages and the Renaissance had the relationship "cultureculture", which looked like the relationship "Antiquity-Middle Ages", "Antiquity-Renaissance", ancient cultures fit into the framework of the association "nature-culture", contemporary culture is based on the association "nature - (culture - culture) - culture", which is characterised by

9 Lehenkyi Yu. H. (2005) Ob arkhitekture (ocherki teorii dizayna inter'era) [On architecture (essays on interior design theory)]. Kyiv: KNUKiI, pp. 36-37. 
a return to nature as to the super value of human existence"10. Let's add to this triad another model of a "meta cultural polylogue" (the communicative universe of cultural creation as multiculturalism), which becomes the leading reflexive regulative of the interpretation of the post-modernism culture.

Thus, the dialogue "culture-nature" (technological understanding of culture) corresponds to the model of "reflection into oneself" reflection as a kind of reflexive rotation on oneself of the boundary situation of culture and nature distribution; the dialogue "culture-culture" as a negation of the previous culture (antiquity) in the Middle Ages, the revival of the values of antiquity in the Renaissance and the emergence of creativity as a "product from nothing" corresponds to the "reflection into something else" model; the dialogue "culture - (culture - culture) - nature" (ecosystem understanding of culture) corresponds to the "reflection over practice" model; the model of "metacultural polylogue" corresponds to the "reflection from the middle of practice" model, that is, the constitution of the universe of culture in each individual practice.

The next step in the reconstruction of the cultural integrity of informātiō is the definition of the subjects of cultural creation as certain producers for the dialogue of cultures. Again, let us turn to Yu. Lehenkyi: "A reflective subject in the history of culture can be represented as:

- a powerful absolute being that enters the consciousness of all possible participants in the dialogue developing in itself the polyphonic fabric of agon, the dialectic of reflection into something else, without leaving the circle of its consciousness (this is the formula for expressing thoughts in the first person in the culture of Ancient Egypt, for example: "I - the one who existed as Khepri (the sun god), I existed, and everything existed"). This type of reflection is characterised by the generalisation in the formula "I - the one" of all possible "the I";

- a dialogic being, where "the one" seems to have access to the consciousness of the reflective and agon unfolds between two (or more) hypostases of "I" (this is the transcendental subject of the classics and all dialogical concepts of the subject of culture). The transcendental subject has "access" to his consciousness only from the consciousness of the individual, but is constructed as a super-individual "I" that reflects into oneself another consciousness;

${ }^{10}$ Lehenkyi Yu. H. (1966) Kul'turologiya izobrazheniya (opyt kompozitsionnogo sinteza) [Cultural Studies in the image (experience of compositional synthesis)]. Kyiv: DALPU, p. 179. 
- a dialogic subject, which produces the world with consciousness, which is always immanent to consciousness (Husserl's version of reflection);

- a fragmented dialogic matter, which "gathers" in different versions of reflection on a particular "structureless" cultural whole (post-modern philosophical practice)" $"$.

The next step in culturological reconstruction is the need to reflect the informātio as the integrity of cultural creation in the modes of the possible (transcendental method), existing (phenomenological approach) and postexisting (dialectical method). The fact is that the reflective subject of culture is not only a producer of knowledge, thought, cultural values, but also a bearer of the cultural and historical potential of a particular era, which is expressed, in particular, in the corresponding information universe.

Therefore, perfect model correlations make it possible to talk about the evolution of information culture as certain integrity of informātiō interpretation, representation, the concept of something and informare - the ability to give form, teach, think, represent. In archaic cultures and antiquity (the first wave of civilisational development, according to A. Toffler), the dogma of behaviour (mythologised, religiously defined) produces the informational integrity of culture according to a monistic ontology of a cosmological type; in medieval culture (the second wave, according to A. Toffler), the ecstatic of the state produces informational messages as divine revelation, communion, liturgy; the time of modernity and postmodernity (the third wave) actualises the activity of the dominant business, where the phenomenon of information is again mythologised and turns into a certain secular religion of the corporate type, a differential ontology for the elite with the correlation of elitism and egalitarianism.

\section{The Phenomenon of Information in Culture Field}

Analysing the concepts of the modern stage of society development, it is necessary to emphasise that: "in the context of terminological improvisation and the practice of scattered analytics of certain aspects of social structures of both the information society and similar forms of social reality, the most effective methodological approach is not aimed at an eclectic combination of modern research on the functioning of various society's forms, but at the identification of common features of transformational changes in general

${ }^{11}$ Lehenkyi Yu. H. (1997) Zobrazhennia yak kultura: filosofskyi analiz [Image as culture: philosophical analysis] (Doctoral dissertation), Kyiv: Instytut filosofii NAN Ukrainy, p. 25. 
and the systematisation of specific attributes inherent in the multidimensional social plane" - M. Shmyhol. ${ }^{12}$

F. Webster notes: "The increase in the amount of information at the time of current changes means much more than just an increase in the number of "messages" to the public. It is known that the development of information and communication technologies increases anxiety and confusion in the minds: the use of computers in factory production means that more jobs there will not be expected, in the future, there will be other jobs that will require knowledge of the computer. Moreover, computerisation accelerates the constant change here and now, which means that in the future, there will be an even greater adaptation of the workforce to new conditions. The whole world means not only that it has become easy to communicate with friends and relatives all over the planet if there is a telephone, Internet cafe or computer terminal somewhere nearby, but also that economic and political strategies can, or rather should, be developed and take into account global factors" $" 13$.

The concepts of the phenomenon of information in culture field are presented as a transitional stage from industrial to a post-industrial society, as a transition from modernity to postmodernity, as a transition from organised to disorganised capitalism, the information turn reveals the "end of history", according to F. Fukuyama et al. The so-called "regulation school" is busy defining the regeneration of capitalist production systems under the condition of globalisation.

F. Webster makes such a remark about the regulation school: "In short, it was a period of expansion, when mass production and consumption were balanced when state participation in the economy maintained harmony when government measures on social security contributed to economic balance and social stability"14. Globalisation led to the decline of Fordism. The processes of modernisation, the expansion of transnational corporations, the clustering of production and services direct to the globalisation of the market, "the whole world is becoming a market", according to F. Webster ${ }^{15}$.

12 Shmyhol M. F., Yushkevych Yu. S. (2019) Eksplikatsiia kontseptosfery filosofskoho dyskursu fenomena "informatsiine suspilstvo" [Explication of the conceptual sphere of the philosophical discourse of the phenomenon "information society"]. Hileia: naukovyi visnyk, vol. 144(2), pp. 127-131.

13 Webster F. (2003) Teorii informatsionnogo obshchestva [Information Society Theories]. Moscow: Aspekt Press, p. 83.

14 Webster F. (2003) Teorii informatsionnogo obshchestva [Information Society Theories]. Moscow: Aspekt Press, p. 87.

15 Webster F. (2003) Teorii informatsionnogo obshchestva [Information Society Theories]. Moscow: Aspekt Press, p. 94. 
"Post-fordism" as a reality of cultural creation is a stage of post-modern models of regulation creation, the essence of which F. Webster defines as follows: "There was a tendency to get rid of labours, which was a necessary reaction of corporations to market stagnation, but this tendency turned out to be long-term in two directions. Firstly, what was euphemistically called job cut continued until the 1990s and beyond, while more successful corporations were able to grow "with job cuts". $<\ldots .>$ Secondly, the postfordistic organisation is often considered to tend vertical disintegration. Instead of producing as much as possible in one structure, the firm seeks to conclude as many contracts with third-party enterprises"

Economic reality prompts the legitimisation of new trends in financial regulation, the dictate of the market remains stable even with the decentralisation of production. The product is replaced by service, information technology. The model of "information capitalism" by M. Castells quickly gained supporters. "Some observers put Castells on a par with Karl Marx, Max Weber and Emile Durkheim. I share this opinion because I am convinced that Castells' work is a vivid description of the main characteristics and dynamics of the development of the modern world, full of knowledge, imagination and intellectual rigour. Anyone who seeks to study the role and characteristics of information - which involves trying to understand the main driving forces of social life - and how information is embedded in change and the acceleration of these changes, can not help but turn to the work of Manuel Castells", - says F. Webster ${ }^{17}$.

So, the information age, like the information society, arises due to the expansion of networks of information and communication technologies. Network technologies are replacing economic determinism. "Networked communities" encourage "networked entrepreneurship" in multinational corporations. However, F. Webster quickly discloses Castells' western: "Castells's arguments are as follows: how television plays a major role in politics not through specific content, but because one cannot engage in politics without dealing with television, and the role of networks is not in their content but the very fact of access to networks. Therefore, the most important for culture is the issue of access to the network, since only this makes it possible to communicate with anyone, anytime" ${ }^{\text {18. }}$.

16 Webster F. (2003) Teorii informatsionnogo obshchestva [Information Society Theories]. Moscow: Aspekt Press, p. 103.

17 Webster F. (2003) Teorii informatsionnogo obshchestva [Information Society Theories]. Moscow: Aspekt Press, p. 130.

18 Webster F. (2003) Teorii informatsionnogo obshchestva [Information Society Theories]. Moscow: Aspekt Press, p. 141. 
The Castells model has the features of the westernisation of post-fordistic capitalism, as well as the model of J. Habermas, which is clearly "sick" by the post-modern romanticisation of information and communication technologies. J. Habermas defined ideal communication conditions:

„1. Anyone capable to communicate and act can participate in the discourse.

2. a) Anyone can problematise any statement.

b) Anyone can speak in discourse with any statement.

c) Anyone can express his views, desires, needs.

3. No one who participates in the discourse should experience both internal and external obstacles in the form of compulsion" ${ }^{\prime 1}$. The cultural implications of both the first and the second author are the freedom that the consumer of information receives from participating in the discourse. The culture is interpreted as a series of general discourses, and the object-product is replaced by service, network technologies. The most important result is the occurrence of virtual network communities that are easily created and easily disappear from the horizon of cultural creation.

D. Schiller loses the romanticisation of the information phenomenon in the era of globalisation and, in turn, universalises the information model of the market, postulates the model of the "information empire" ${ }^{20}$. There are no remnants of information romanticism, because universality, totality, the imperial reality of information and communication technologies are postulated. D. Schiller is essentially a theorist of consumer capitalism and consumer culture as an "empire" of a network society.

E. Giddens is rightfully considered the father of reflexive information theory. F. Webster states: "Giddens considers himself to be the successor of the classical society theorists, first of all, Karl Marx, Emil Durkheim and Max Weber. Like this big trinity, Giddens seeks to explain the totality of changes that took place somewhere in the middle of the 17th century, which are called the transition to a new time. The purpose of sociology and precisely its emergence is connected with this gap; then, in place of the "traditional" society, a new one arose with its industrial production, bureaucracy, urbanisation, science, a new attitude to nature, with many innovations in social institutions and public relations, which we now call modernisation" 21 .

${ }^{19}$ Ermolenko A. M. (1999) Komunikatyvna praktychna filosofiia [Communicative practical philosophy]. Kyiv: Libra, p. 38.

${ }^{20}$ Schiller D. (1999) Digital Capitalism: Networking the Global Market System. Cambridge, MA: MIT Press

21 Webster F. (2003) Teorii informatsionnogo obshchestva [Information Society Theories]. Moscow: Aspekt Press, p. 276. 
However, globalisation destroys the traditional mode of information perception, the "human rights regime" becomes even less effective, activities of transnational corporations are monitored only in the mode of information segmentation since it cannot otherwise be presented as integrity. So, "reflexive modernisation becomes a two-faced Janus", says F. Webster ${ }^{22}$.

Postmodernist interpretations of the information phenomenon border on its denial not on the phenomenological, but on the substantive level. We will provide a descriptions list of the features of information and communication technologies of post-modernism, according to F. Webster. "These are the features:

- rejection of the way of thinking inherent in the modern era, its values and customs;

- rejection of any claims to establish the truth since only its versions exist;

- rejection of the desire to clarify the meaning, since there are countless meanings, and this does the search for meaning hopeless;

- pleasure in stating the differences between subjects: in interpretations, values and styles;

- special attention to receiving pleasure, unreflected life experience, to sublimation and pure apperception;

- the pleasure of superficial visibility, variety, change, parody and stylisation;

- recognition of the existence of creativity and imagination in an ordinary person is based on a disregard for deterministic theories of human behaviour" "23. J. Baudrillard believes that the culture of post-modernism is the culture of signs because there are so many signs that the culture has no sense of the designation ${ }^{24}$. J.-F. Lyotard claims that information becomes a commodity; market mechanisms work in the information sphere ${ }^{25}$.

A special place of the functioning of information and communication technologies is the culture of the post-communist space with its difficult correlation of autochthonous capitalism and information circulating in public space as outright propaganda. V. Fedotova, V. Kolpakov, N. Fedotova define several periods of transformation in modern society: "Changes in the

${ }^{22}$ Webster F. (2003) Teorii informatsionnogo obshchestva [Information Society Theories]. Moscow: Aspekt Press, p. 309.

23 Webster F. (2003) Teorii informatsionnogo obshchestva [Information Society Theories]. Moscow: Aspekt Press, pp. 330-331.

${ }^{24}$ Baudrillard J. (2000) Simvolicheskiy obmen i smert'. [Symbolic exchange and death] Moscow : Dobrosvet

${ }^{25}$ Lyotard J-F. (1993) Political Writings (trans. by Bill Readings and Kevin Paul Geiman). London: UCL Press. 
types of modernity corresponded to the historical weakening of the social identity construction: from the predetermined and natural to the socially achieved, quasi-natural and what can be chosen and socially improved. Three types of modernity First (liberal), Second (organisational), Third (which can be characterised as the second globalisation and the establishment of the Westphalian system of nation states) correspond to three types of identity.

An autonomous responsible individual is a modular person, an economic person of the First modernity; a mass person who is manipulated by organisations, technostructures, who received distributional justice through social democratic institutions, who became consumers in a consumer society, rebels at the time of its crisis. The Third modernity has not yet formed, it begins in the 1990s of the twentieth century, and the person here at first tried to assimilate the features of the First modernity - to be economical, remaining a mass consumer, which is not characteristic of the First modernity. The dynamics of these properties is extremely disturbing. Alienation, loneliness, egoism and narcissism are growing, the mass person is formed thanks to the media, without those features of mass character (ordinariness) that J. Ortega y Gasset and M. Bloomer found in it. Baudrillard defines him as the average person who has been formed thank to the TV",26. These changes, in one way or another, have the basis of information realities that form the identity of the subject of post-communist culture.

V. Fedotova, V. Kolpakov, N. Fedotova mark the identity crisis as:

" - the ratio of past and new identities where they arise does not depend on their number, but is a certain integral of an individual, community, corporation or country. In this sense, it is difficult to talk about multiidentity, while multiculturalism is quite possible;

- multi-identity is possible, but it is the essence of the identity problem (S. Huntington);

- multi-identity is created, but this removes the issue of identity. Sometimes this position is taken to the point that identity today just does not matter.

Problems develop into a crisis if there is no definite intersection, no consensus between different interpretations of the personality meaning"27. Consequently, human identity as a multi-identity in the era of globalisation

${ }^{26}$ Kolpakov V. A., Fedotova V. G., Fedotova N. N. (2008) Global'nyy kapitalizm: tri velikikh transformatsii [Global Capitalism: Three Great Transformations]. Moscow: Kul'turnaya revolyutsiya, p. 327.

${ }^{27}$ Kolpakov V. A., Fedotova V. G., Fedotova N. N. (2008) Global'nyy kapitalizm: tri velikikh transformatsii [Global Capitalism: Three Great Transformations]. Moscow: Kul'turnaya revolyutsiya, p. 327. 
is becoming one of the outstanding factors of perception, dissemination and information transformation.

E. Bystrytskyi notes the unity of post-communist and post-modern identity of a person: "The core of such a system of assumptions that we, taking into account the concept of J. Habermas, will call it the Modern project, is an assumption of historical development. It is primarily about understanding the history of progress in the self-consciousness of humankind, about the idea of emancipation through the progress of Mind, science (or social action directed by scientific knowledge - marxism), as well as about achieving maximum material and spiritual well-being on this path. This ideological basis (starting with Spinoza, Hobbes, thinkers of the Enlightenment and up to Hegel, Marx, Kant, Spencer et al., with all their differences), determines the foundations of political thought - the political ontology of the Modern project" 28 .

According to O. Dovhan, "the fundamental ideas of the Hobbesian and Kantian doctrine of the safe existence of the individual, society and the state, the ways of ensuring peace and security acquire special relevance in current conditions. The ideas of these thinkers about security issues continue to play a huge role in understanding where we are and where we must move to get on the right path to a future of secure existence". ${ }^{29}$

The culture of the post-communist space is dominated by the communicative locus of information. The messages of the TV news program set the format for the exclusive reality of acquaintance with events in the world, focused on the expressive factuality of the screen message, which gradually turns into a show in its various configurations, from reality show to political debate. A. Novikova states: "Synthesising in their structure various genres, methods of influencing the audience, television shows of all kinds are trying to achieve one goal - to cause outbursts of emotions in the viewer. Neither the artists nor the audience hides that everything that happens during this or that show, is nothing more than a game, but emotions and excitement do not lose anything from this" ${ }^{\prime 30}$.

28 Bystrytskyi E. (1995) Postkomunistychna filosofiia postkomunistychnoi doby [Post-communist philosophy of the post-communist era]. Politolohiia postkomunizmu [Political science of post-communism]. Kyiv: Politychna dumka, p. 18.

${ }^{29}$ Dovhan O. D., Tkachuk T. Yu. (2018) Naukova refleksiia informatsiinoi bezpeky Ukrainy: vid pozytyvizmu do metafizyky prava [Scientific reflection of information security of Ukraine: from positivism to metaphysics of law]. Informatsiia i pravo, no 4. pp. 79-89.

${ }^{30}$ Novikova A. (2008) Sovremennye televizionnye zrelishcha: istoki, formy i metody vozdeystviya [Modern television shows: origins, forms and methods of influence]. St.Petersburg: Aleteyya, p. 160. 


\section{CONCLUSIONS}

Therefore, it is certain that the phenomenon of information as a reality of culture has an ontology of traditional, antiquated cultures and antiquity, which is determined by the imperative of reflection "I am the one who...", the ontology of a detailed dialogue of cultures of medieval culture as creative drives to creativity, the ontology of modern and post-modern thinking as a game, reflex-incentive ironic reflection from the middle of practice, reflection on practice, reflection in the other and reflection in oneself. The information and communication reality of culture is analogous to the human-dimensional constants of this culture: mythological, theological, anthropocentric, epistemological, and ontological. The phenomenon of information is neither a monistic ontological space of cultural creation nor a diffuse simulacrum field of loss of meaning of an information message. The information integrity of culture is formed as a cultural and historical reality of human activity, behaviour and condition.

Behind certain models of cultural subjects and reflection "hides" a certain informātiō model where absolute transcendentalism is as a mythological attitude (baseless ontology of the information absolute); information exists, regardless of whether a person uses, perceives, understands it; epistemological transcendentalism, where the ontology informātio is a purely ideal matter of cultural creation; information is as a constitutional fact of the consciousness of a mathematician, programmer, sociologist, artist, etc.; information is as a deconstructive fact of postmodern allusions.

Therefore, the cultural entity should be simulated as the absolute integrity of its subject intentions. Thus, archaic cultures, the culture of antiquity, the dialogue of cultural creation "culture - nature" corresponds to behaviour as a moral regulator of taboos, prohibitions, ethical maxims; medieval culture, the dialogue "culture - culture" corresponds to the state as the integrity of ecstatic perception of the world in the dichotomy of the created and non -created world, God and man; the culture of early and classical modernity, the dialogue "culture - (culture - culture) - nature" corresponds to activity as a unity of goal-setting and goal-making; the culture of post-modernism, the contemporary state multiculturalism corresponds to a symbiosis of activity, state, and behaviour according to the dominant state.

\section{SUMMARY}

The information space of culture in general and cultural practices related to the concentration, transformation and preservation of information as a resource of humanitarian background holders (libraries, archives, museums, 
exhibition and showrooms) is subjected to scientific scrutiny in Computer Studies, Cybernetics, Social Studies, Cultural Ecology, Communicology. The purpose of the article is to define communicative society not as planned constructs of a priori post-modern poetics, but as a cultural phenomenon that accumulates the intentions of cultural creation of archaic cultures, antiquity (the latest myth-making), the Middle Ages and early modern (creativity, information romanticism), classical modern and postmodern (Westernisation, modernisation of information culture). Scientific novelty provides its interpretation of the leading concepts of information and communication society as a cultural phenomenon. Conclusions. Therefore, the cultural entity should be simulated as the absolute integrity of its subject intentions. The information and communication reality of culture is analogous to the human-dimensional constants of this culture: mythological, theological, anthropocentric, epistemological, and ontological. The phenomenon of information is neither a monistic ontological space of cultural creation nor a diffuse simulacrum field of loss of meaning of an information message. The information integrity of culture is formed as a cultural and historical reality of human activity, behaviour and condition.

\section{REFERENCES}

1. Baudrillard J. (2000) Simvolicheskiy obmen i smert'. [Symbolic exchange and death] Moscow : Dobrosvet. (in Russian)

2. Bell D. (1996) Prykhid postindustrialnoho suspilstva [The arrival of post-industrial society]. Suchasna zarubizhna sotsialna filosofiia [Modern foreign social philosophy]. Kyiv: Lybid, pp. 194-250.

3. Bystrytskyi E. (1995) Postkomunistychna filosofiia postkomunistychnoi doby [Post-communist philosophy of the post-communist era]. Politolohiia postkomunizmu [Political science of post-communism]. Kyiv: Politychna dumka, pp. 13 - 67.

4. Dovhan O. D., Tkachuk T. Yu. (2018) Naukova refleksiia informatsiinoi bezpeky Ukrainy: vid pozytyvizmu do metafizyky prava [Scientific reflection of information security of Ukraine: from positivism to metaphysics of law]. Informatsiia i pravo, no 4. pp. 79-89.

5. Ermolenko A. M. (1999) Komunikatyvna praktychna filosofiia [Communicative practical philosophy]. Kyiv: Libra. (in Ukrainian)

6. Informatsiya [Information]. Retrieved from: https://ru.wikipedia.org/ wiki (accessed 9 October 2020).

7. Kolpakov V. A., Fedotova V. G., Fedotova N. N. (2008) Global' nyy kapitalizm: tri velikikh transformatsii [Global Capitalism: Three Great Transformations]. Moscow: Kul'turnaya revolyutsiya. (in Russian) 
8. Lehenkyi Yu. H. (1966) Kul'turologiya izobrazheniya (opyt kompozitsionnogo sinteza) [Cultural Studies in the image (experience of compositional synthesis)]. Kyiv: DALPU. (in Russian)

9. Lehenkyi Yu. H. (1997) Zobrazhennia yak kultura: filosofskyi analiz [Image as culture: philosophical analysis] (Doctoral dissertation), Kyiv: Instytut filosofii NAN Ukrainy.

10. Lehenkyi Yu. H. (2005) Ob arkhitekture (ocherki teorii dizayna inter' era) [On architecture (essays on interior design theory)]. Kyiv: KNUKiI. (in Russian)

11. Lyotard J-F. (1993) Political Writings (trans. by Bill Readings and Kevin Paul Geiman). London: UCL Press.

12. Novikova A. (2008) Sovremennye televizionnye zrelishcha: istoki, formy i metody vozdeystviya [Modern television shows: origins, forms and methods of influence]. St.Petersburg: Aleteyya. (in Russian)

13. Schiller D. (1999) Digital Capitalism: Networking the Global Market System. Cambridge, MA: MIT Press.

14. Shmyhol M. F., Yushkevych Yu. S. (2019) Eksplikatsiia kontseptosfery filosofskoho dyskursu fenomena "informatsiine suspilstvo" [Explication of the conceptual sphere of the philosophical discourse of the phenomenon "information society"]. Hileia: naukovyi visnyk, vol. 144(2), pp. 127-131.

15. Stonier T. (1990) Information and the Internal Structure of the Universe: An Exploration into Information Physics. London: SpringerVerlag.

16. Webster F. (2003) Teorii informatsionnogo obshchestva [Information Society Theories]. Moscow: Aspekt Press. (in Russian)

Information about the author:
Horban Yurii
orcid.org/0000-0001-5837-4409

$\mathrm{PhD}$ in Cultural Studies, Associate Professor Kyiv National University of Culture and Arts 36, Ye. Konovaltsia St., Kyiv, 01133, Ukraine 